\title{
Sexual Difference in/and the Queer beyond of Ethics
}

\section{Stephen Seely}

In her recent book, Are the Lips a Grave? A Queer Feminist on the Ethics of Sex, Lynne Huffer offers a daring call for a reconsideration of the rifts between feminist and queer theory in order to develop a "queer feminist ethics of eros" (Huffer 2013, 44). Arguing that sexual ethics lies at the fractured nexus between feminist and queer theory, Huffer seeks both to restore "a claim to an ethical queer feminism" and to transfigure ethics as "erotic living" (22). This project is clearly staged in the book's titular chapter, which provocatively brings together Michel Foucault's and Luce Irigaray's respective reformulations of sexual ethics with the so-called antisocial queer theory of Leo Bersani and Janet Halley. To my mind, one of the most invaluable contributions of Huffer's book is her queer reclamation of Irigaray's philosophy of sexual difference-a philosophy that many feminist and queer theorists alike have dismissed as irredeemably essentialist, conservative, heteronormative, and even homophobic, transphobic, and racist. ${ }^{1}$ For Huffer, however, "Irigaray's . . . absence from queer theory is evidence of a forgetting of her radical feminist practice as an always already queer method" $(2013,42)$. Taking off from Huffer's queer feminist rereading of Irigaray, I want to further queer ethics by exploring the relationship between ethics and sexual difference as it has been thought in European philosophy. First, I offer a critique of the conflation of queerness and "negativity" in antisocial queer theory and the abdication of ethical responsibility it ultimately entails. Following both Irigaray and Jacques Derrida, I then argue that sexual difference is wholly other (tout autre) to "the ethical" as it has been thought within phallogocentrism and, thus, I contend that justice demands a 
fidelity to this radical otherness of sexual difference. Queerness, I suggest, names precisely this "beyond" of the ethical — that is, sexual difference "itself" — and, thus, ironically, both queer and feminist theory must struggle for the heteros of sexual difference, beyond any distinction between she/he, hetero-/homosexual, friendship/love, or sex/eros.

To think through the relationship between queerness, sexual difference, and ethics in European philosophy requires a return to one of the least queer thinkers: G. W. F. Hegel. For Hegel, the ethical order (die Sittlichkeit) is the third and highest of the "spheres of right," superseding and encompassing both abstract right (das abstrakte Recht) and morality (die Moralität). It is only in the ethical order, the order of social relations, that the subjective and objective, universal and particular dimensions of the will are brought together:

The social order [die Sittlichkeit] is the unity, and ... the reconciliation also of the subjective good with the objective absolute good. Morality is the general form of the will as subjective; but the ethical order is not simply the subjective form and the self-determination of the will, but contains their conception, namely, freedom. Neither right nor morality can exist independently, but must have the ethical as its pillar and support. In right is wanting the element of subjectivity and in morality is wanting the objective, so that neither has any actuality. $(2005,75)$

In Hegel's transindividual philosophy, against modern atomistic political philosophies, the concept of freedom can be actualized only in the ethical order through relations with others. And 
for Hegel, sexual difference plays a pivotal role in the entry into the ethical order in the form of marriage and the family. In love, the relation in which one first feels unity with another, the "natural determinacy of the two sexes acquires intellectual and ethical significance" $(2005,87)$; however, because love is merely a "feeling," it must be given objective reality in marriage in order to acquire proper ethical status $(2005,83)$. Yet, this "legal ethical love" does not find its fullest concrete existence until the birth of a child, the physical embodiment of the unity of the sexes. ${ }^{2}$ Despite its significance, however, the family is merely the first element of the ethical order, and its unity must be dissolved and superseded to enter civil society and, ultimately, the State.

Given that, according to Hegel, the reproductive nuclear family is the foundation of ethical and social life (88), and to be an ethical person at all one must marry someone of the "opposite sex" (84), we would seem to have here the paradigmatic heteronormative ethical philosophy. ${ }^{3}$ As such, it would appear to be hopelessly susceptible to queer critique, especially that offered by Lee Edelman in his (in)famous No Future: Queer Theory and the Death Drive. For Edelman, the social order is grounded in a constitutive heteronormativity and what he calls "reproductive futurism" that positions the figure of the Child as the horizon and beneficiary of every social and political action (2004, 2). If, as Hegel would have it, the ethical order, and therefore the society and politics it sustains, are rooted in the reproductive structure of the heterosexual family, then queers are constitutively excluded from all ethical, social, and political relations tout court. It is for this reason that Edelman urges queers to inhabit the radical negativity of the ethical order itself: if the ethical order depends on the fantasy of a future without queers, a future of complete actualization without negativity, then queers should embody 
the negativity they are figured as and "insist that the future stop here" $(2004,31) .{ }^{4}$ For Edelman, this demands queerness as oppositional to all forms of determination:

queerness attains its ethical value precisely insofar as it . . . accept[s] its figural status as resistance to the viability of the social while insisting on the inextricability of such resistance from every social structure. . . The impossible project of a queer oppositionality ... would oppose itself to the structural determinants of politics as such, which is also to say, ... would oppose itself to the logic of opposition ... the queer comes to figure the bar to every realization of futurity, the resistance, internal to the social, to every social structure or form. $(2004,3-4)$

Moreover, in what is at least an implicit reference to Hegel, Edelman argues that queerness harnesses sexuality's “stubborn denial of teleology, its resistance to determinations of meaning ... and, above all, its rejection of spiritualization through marriage or reproductive futurism" (2004, 27). For Edelman, then, queerness names the beyond of Sittlichkeit - that which cannot be appropriated or incorporated into, and, what is more, that which endangers the predetermined route of ethics from the family to society to the state.

While I agree with Edelman that queerness names the beyond of the ethical, and while I also agree that this is precisely queerness's "ethical value," I argue that Edelman's conflation of queerness with radical negativity and antisociality does not ultimately challenge the heterosexism of Sittlichkeit in the way that he suggests. In the first place, Edelman's contention 
that queerness names the resistance to all structural determinations is merely an instantiation of what Hegel calls "abstract negation" or "negative freedom." Indeed, Hegel describes this form of negation in words that could have been written about Edelman himself:

It reckons any content as a limit and flees from it. If the will determines itself in this way, or if representational thought considers this aspect in itself as freedom and holds fast to it, this is negative freedom . . . becoming actual it assumes both in politics and religion the form of a fanaticism, which would destroy the established social order, remove any individuals suspected of desiring any kind of order, and demolish any organization which then sought to rise out of the ruins. Only in destroying something does this negative will feel that it has reality. (2005, 6)

Positing queerness as a form of abstract negation or negative freedom is thus not to give it a place outside of the Hegelian ethical dialectic at all, but is instead, to lock it into a reactive, circular dialectic — what Hegel would call a "bad infinite" — with all forms of social order. ${ }^{5}$ And unless Edelman's form of queerness is to remain abstract or purely theoretical—which would almost certainly mean having absolutely no impact on the heteronormativity of Sittlichkeit whatsoever - it must be actualized, and to actualize queerness as the negation of "every social structure or form" could lead only to the following: 
- a nihilistic pleasure-seeking or "acting out" (necessarily nihilistic because the attribution of any value to the action would be to give it a structural and symbolic determination);

- the conflation of queerness and sociopathy; and

- a form of queer Jacobinism in which queerness's form as the negation of structural determination is more important than any particular action, and in which any "queer" may be accused of betraying queerness by acting according to social or political content. ${ }^{6}$

It is therefore difficult to see how such a form of nihilism (literally, that which negates all value) could have the "ethical value" that Edelman claims it has, or how it could ultimately offer any serious challenge to the heteronormativity of Sittlichkeit.

Yet, given that the ethical itself, and thus the social and political, is, following Hegel, founded on a reproductive heterosexuality, how can queerness pose a challenge without being locked in as the perpetual negation of all order? How can queerness truly be beyond Sittlichkeit? Let us return again to the place of sexual difference at the entry into the ethical order, this time from the perspective of Irigaray. From Speculum on, Irigaray has been engaged with precisely this part of Hegel's thought. As we saw, for Hegel, the "natural determinacy of the sexes" gains its ethical significance first in legal marriage and second in the form of a child. And yet, because Hegel denies women the capacity to universalize, their role as wives and mothers is the culmination of their participation in the ethical order, whereas man's "ethical activity" extends beyond the family into the civil society and the state $(2005,164-66)$. This has two effects that Irigaray brings out throughout her oeuvre: first, any entry women make into the civil society or 
the state can only be made as a "universal" (i.e., masculine disguised as "neutral") subject; and second, any potential creativity of sexual difference is expressed only in the form of a childsexual difference thus becomes purely instrumental, its energy never cultivated or spiritualized into a creative force for ethical relations beyond procreation and family life. ${ }^{7}$ While many have read Irigaray as concerned only with the abjection of "Woman" from the ethical, social, and political order, her intervention is actually much stronger: sexual difference "itself" is the other of Sittlichkeit. ${ }^{8}$ As such, all ethical, social, and political relations take place between men and their specularized "others" within a representational economy of the Same, a situation that Irigaray notoriously describes as "hom(m)osexuality" (1985b, 171) Irigaray's analysis of the "hom(m)osexuality" of phallogocentrism extends to all of European philosophy, including both Hegel's ethics and psychoanalysis, and explains both the exclusion of women from all social, political, economic, and ethical exchange as well as the abjection of male homosexuality. ${ }^{9}$ As she puts it,

The use of and traffic in women subtend and uphold the reign of masculine hom(m)o-sexuality, even while they maintain that hom(m)o-sexuality in speculations, mirror games, identifications, and more or less rivalrous appropriations, which defer its real practice. Reigning everywhere, although prohibited in practice, hom $(\mathrm{m}) \mathrm{o}$-sexuality is played out through the bodies of women, matter, or sign, and heterosexuality has been up to now just an alibi for the smooth working of man's relations with himself, of relations among men. 
$(1985 b, 172)$

Moreover, two central concepts of queer critique - heteronormativity and reproductive futurism - now become intelligible as processes that reproduce and guarantee the phallocentric hom(m)osexuality of Sittlichkeit, both of which are on display in Hegel's philosophy: "heteronormativity" being the effect of the compulsory exchange of women and the prohibition against "actual" homosexuality that keeps the fraternity of the ethical order running, while "reproductive futurism" (i.e., the Child as the exclusive figure of the future) is precisely the result of the fact that within phallogocentric hom(m)osexuality "there is no sexual relationship" (Lacan 1999, 126) — nothing creative in sexuality besides a child is given ethical actuality and therefore "the Child" is saddled with the full burden of giving any and all meaning to the sexual "relation," as well as to the ethical, social, and political order grounded on it. Within this phallocentric hom(m)osexuality, the difference between "man" and "woman," as well as that between "homosexuality" and "heterosexuality," is a difference that is not one; indeed, within such an order, man "relates" only with himself $(1985 b, 193)$. And that sexual difference is excluded in the hom(m)osexuality of Sittlichkeit means that we have no real place for the heteros - difference, otherness - in our configurations of sexuality: the social, political, and ethical force of sexual difference remains yet to come. Thus, those who see in Irigaray's later works the ultimate dream of heteronormativity and read her texts as philosophical Harlequin romance novels fail to grasp the full magnitude of her intervention: her writings on sexuate rights, the spirituality of desire, the creative potential of sexual difference beyond pro-creation, and new ways of loving and sharing with the sexuate other are all attempts to unsettle the 
hom(m)osexuality of Sittlichkeit through the irruptive force of sexual difference-what Huffer refers to as queer "hetero-difference" $(2013,37)$ - a difference beyond all reigning oppositions between man/woman, heterosexuality/homosexuality. ${ }^{10}$

As Derrida forcefully tells us time and again, what is excluded from any system remains to haunt that system and prevent it from full self-enclosure. ${ }^{11}$ And it is precisely the remains of this other that call us to responsibility: ${ }^{12}$ justice, beyond the ethical and the political, demands the deconstruction of all determinations, but only in the name of the undeconstructibility of the other, without which deconstruction is inseparable from the nihilistic abstract negation Hegel decries. ${ }^{13}$ As the other of phallogocentric hom(m)osexuality, sexual difference remains and haunts Sittlichkeit with the promise of an otherness-a heteros-sexuality - to come. The "ethical value" of queerness, then, is not exactly as Edelman suggests (i.e., the resistance to every social structure or form); rather, queerness marks the trace of sexual difference that prevents the selfenclosure and auto-reproduction of the ethical order to keep open a space for the other, the heteros, to come. ${ }^{14}$ Queerness's resistance to, or deconstruction of, heteronormativity and reproductive futurism must therefore be undertaken precisely in the name of this other-sexual difference "itself." Irigaray's ethics of sexual difference is thus, from this perspective, a queer ethics of the other-indeed, a queer struggle for justice beyond "the ethical." It is this ethical fidelity to the otherness of the other that leads to the difference in Irigaray's use of the negative as compared to Hegel's and Edelman's. As Irigaray writes,

My use of the negative serves to maintain irreducibility of the you with respect to the I, that is, the insuperable and unknowable existence, being and truth of the 
other. While Hegel somehow attempts to reduce the all to the same, I stress the necessity of recognizing the existence of the unknowable, the inappropriable objectivity and subjectivity that the other represents. $(2008,127)$

Even though Edelman posits queer negativity as that which disrupts the smooth teleological progression of the Hegelian ethical dialectic, his reduction of queerness to abstract negation locks it into a perpetual dialectic with the social order that incessantly seeks to exclude it. For Irigaray, on the contrary, the negative is beyond the dialectic altogether; it is precisely the registration of the impossibility of any system to fully enframe its other(s), that is, it is the trace of sexual difference. In this queer ethics of the beyond, or this queer beyond of ethics, queerness is neither about the sex of the partners nor the acts in which they engage; rather, it is a completely aleatory encounter with/in the beyond of Sittlichkeit: an encounter that takes place beyond the ethical, political, and social but is not an(ti)ethical, a(nti)political, or a(nti)social—an encounter with the other that eludes any distinction between he/she, sex/eros, heterosexual/homosexual, love/friendship, or any other opposition set up by phallocentric hom(m)osexuality. There is an ironic sense, then, in which queer politics is a struggle for the heteros in sexuality — a task for which a closer alliance between feminist and queer theory, such as that bravely offered by Lynne Huffer, will be indispensible.

Stephen D Seely is a postdoctoral fellow in the Institute of Advanced Study and the Social Theory Centre at the University of Warwick (UK). He recently earned his $\mathrm{PhD}$ in Women's \& Gender Studies from Rutgers University and he specializes in feminist, decolonial, and 
Continental philosophy. His work has appeared in WSQ: Women's Studies Quarterly, The Australian Feminist Law Journal, borderlands, and Social Text and his book, The Spirit of Revolution: Beyond the Dead Ends of Man (co-authored with Drucilla Cornell) was published by Polity Press in 2016. He can be reached at stephen.seely@gmail.com

Notes

1 Huffer discusses many of these critiques in her book. For the most prominent, see the critiques offered by Judith Butler and Drucilla Cornell in Cheah and Grosz 1998.

2 "The unity of marriage which, as substantive, exists only as an inner harmony and sentiment but so far as it exists actually, is separated in the two married persons, becomes in the children a unity, which has actual independent existence, and is an independent object. This new object the parents love as an embodiment of their love.... This process expands into an infinite series of generations which beget and are presupposed" (Hegel 2005, 90).

3 "To enter marriage is an objective determination and hence an ethical duty" (Hegel 2005, 84) "Marriage, and essentially monogamy, is one of the absolute principles on which the ethical life of a community is based" (88). I use the phrase "opposite sex" deliberately because, for Hegel, "natural sexual difference" becomes the opposition between man and woman in the ethical order (87).

4 Edelman does not use the phrase "the ethical order" or "die Sittlichkeit," but rather refers to "the social order," "politics," and "the Symbolic order" (2004, passim). He does, however, make reference to Hegel throughout his work. The Symbolic order in Lacan, and the social and political as described by Edelman, are, I suggest, more or less synonymous with Sittlichkeit in Hegel's philosophy. A deeper engagement with the Lacanian dimensions of Edelman's work, 
and the complex relationship between Lacan and Hegel, is unfortunately beyond the scope of this short paper.

5 "This infinity is spurious or negative infinity, since it is nothing but the negation of the finite, but the finite arises again in the same way, so that it is no more sublated than not.... This process ad infinitum does not go beyond the expression of the contradiction, which the finite contains, that it is just as much something as its other, and [this process] is the perpetual continuation of the alternation between these determinations, each bringing in the other one" (Hegel 1991, 149).

6 Hegel explicitly associates abstract negation with the Terror during the French Revolution: "Of this nature was the terrible epoch in the French Revolution, by which all distinctions in talent and authority were to have been superseded. In this time of upheaval and commotion any specific thing was intolerable. Fanaticism wills an abstraction and not an articulate association. It finds all distinctions antagonistic to its indefiniteness and supersedes them. Hence, in the French Revolution the people abolished the institutions which they themselves had set up, since every institution is inimical to the abstract self-consciousness of equality" (2005, xxxiii). xxxiii 7 For Irigaray's most extensive engagements with Hegel, see Speculum of the Other Woman, I Love To You, and Democracy Begins Between Two.

8 Indeed, as Irigaray argues, within phallogocentrism, "woman" is merely the specular image of “man" (see 1985a).

9 According to Irigaray, actual male homosexual relations are forbidden "because they openly interpret the law according to which society operates, they threaten in fact to shift the horizon of that law. Besides, they challenge the nature, status, and 'exogamic' necessity of the product of 
exchange. ... Once the penis becomes merely a means to pleasure, pleasure among men, the phallus loses its power" (1985b, 193).

10 From this perspective, it is easy to see how Irigaray's later affirmative works, those that are supposedly heteronormative and essentialist, follow directly from her early critiques of phallocentrism. For an overview of the later works, including each of the projects mentioned above, see Key Writings.

11 Derrida makes this point in nearly every text. Most pertinent to the discussion here is Glas, one of Derrida's queerest books, which deals extensively with Hegel, Sittlichkeit, and sexual difference.

12 As Drucilla Cornell puts it in an essay that defends Derrida as indispensible to the deconstruction of phallogocentrism of Lacan, "It is the trace of Otherness, which always remains beyond, that calls us to the ethical relationship" $(1995,791)$.

13 In several of his later writings, Derrida explicitly connects deconstruction with justice as the undeconstructibility of the other/the beyond. For example: "Justice in itself, if such a thing exists, outside or beyond law, is not deconstructible. Nor more than deconstruction itself, if such a thing exists. Deconstruction is justice" $(2002,242)$.

14 In The Politics of Friendship, Derrida claims that phallogocentrism is one of the two "major questions" of deconstruction: "the question of friendship might well be at least an example or a lead in the two major questions of 'deconstruction': the question of the history of concepts and (trivially) so-called 'textual' hegemony, history tout court; and the question of phallogocentrism" (1997, 278). As such, Derrida, particularly his concept of aimance (as love-friendship beyond fraternity and the division between eros and philein), is crucial to a queer feminist ethics of sexual difference. 


\section{$\leq$ REF $>$ References}

Cheah, Pheng, and Elizabeth Grosz. 1998. “The Future of Sexual Difference: An Interview with Judith Butler and Drucilla Cornell.” Diacritics 28 (1): 19-42.

Cornell, Drucilla. 1995. "Rethinking the Beyond of the Real." Cardozo Law Review 16 (3-4): 729-92.

Derrida, Jacques. 1986. Glas. Translated by John P. Leavy and Richard Rand. Lincoln: University of Nebraska Press.

— 1997. The Politics of Friendship. Translated by George Collins. New York: Verso.

—. 2002. "Force of Law." In Jacques Derrida: Acts of Religion, edited by Gil Anidjar. New York: Routledge.

Edelman, Lee. 2004. No Future: Queer Theory and the Death Drive. Durham, NC: Duke University Press.

Hegel, G. W. F. 1991. The Encyclopaedia Logic: Part I of the Encyclopaedia of Philosophical Sciences with the Zusätze. Translated by T. F. Gerates et al. Indianapolis: Hackett Publishing.

—. 2005. Philosophy of Right. Translated by S. W. Dyde. Mineola, NY: Dover Publications.

Huffer, Lynne. 2013. Are the Lips a Grave? A Queer Feminist on the Ethics of Sex. New York: Columbia University Press.

Irigaray, Luce. 1985a. Speculum of the Other Woman. Translated by Gillian C. Gill. Ithaca, NY: Cornell University Press. 
—. 1985b. This Sex Which Is Not One. Translated by Catherine Porter. Ithaca, NY: Cornell University Press.

—. 1991. I Love to You. Translated by Alison Martin. New York: Routledge.

—2001. Democracy Begins between Two. Translated by Kirsteen Anderson. New York: Routledge.

—. 2004. Key Writings. London: Continuum.

- 2008. Conversations. London: Continuum.

Lacan, Jacques. 1999. The Seminar of Jacques Lacan, Book XX: On Feminine Sexuality, the Limits of Love and Knowledge (Encore). Edited by Jacques-Alain Miller. Translated by Bruce Fink. New York: W. W. Norton \& Co. 